\title{
Decision-Making Of Headmasters At Junior High Schools In North Minahasa Regency
}

\section{(A Multi-Case Study On Smp N 1 Kalawat And Smp N 2 Kauditan)}

\author{
Maria G. Tindangen* \\ Joulanda Rawis** 1), Herry Sumual ***2), Orbanus Naharia****3) \\ * Doctoral Program in Educational Management, Manado State University \\ ** Supervisor, Faculty Member, Manado State University \\ *** Co- Supervisor 1, Faculty Member, Graduate Program, Manado State University \\ **** Co- Supervisor 2, Faculty Member, Graduate Program, Manado State University \\ Address: Graduate Campus of Manado State University, Tondano 95618, North Sulawesi, Indonesia \\ www.unima.ac.id \\ Corresponding author's email:.tindangenmaria27@gmail.com \\ Mobile Phone Number: 081244743882 \\ DOI: 10.29322/IJSRP.10.10.2020.p10604 \\ http://dx.doi.org/10.29322/IJSRP.10.10.2020.p10604
}

\begin{abstract}
Decision-Making of Headmasters is a strategy adopted by headmasters to overcome problems encountered by schools in achieving goals. Research objectives: To describe and analyze the decision-making process using passing standards, content standards, management standards. The research methodology employed qualitative approach, informants consisted of headmasters, teachers, students and supervisors. Data were collected using interviews, observation, and documentation. Data processing procedures consisted of data collection, data reduction, data display, and conclusion. Research results: 1a. The decisions of the Headmaster of SMP N 1 Kalawat were made by: involving subordinates, deliberating, concluding, deciding, directing, conducting approaches, distributing tasks, providing incentives, being patient, distributing works until they are done. 1b. graduation standards: improving competence, implementing the 2013 curriculum in learning, curricular and extra-curricular activities. Assessment, determination of graduation. Content Standards: establishing a curriculum development team, making a curriculum, supervising, evaluating. d. Process Standards: facilitating and coordinating, supervising, evaluating. 2a. The decisions the Headmaster of SMP N 2 Kauditan were made by: providing opportunities for subordinates to give input, deliberating, distributing works, paying attention to needs. 2b. Graduation Standards: motivating, carrying out curricular activities and extracurricular activities, supervising, motivating students and teachers, holding tests, holding school examination, holding computer-based national exams. 2c. Content Standards: establishing a curriculum development team, supervising. 2d. Process standards: implementing a school curricula, supervising and providing reinforcement. Conclusion: The decision-making the headmasters is generally good. This can be seen that they are successful in the involvement of subordinates in the decisionmaking process and the Decision-Making of Headmasters is related to passing standards, content standards, process standards.
\end{abstract}

Keywords: decision-making of headmasters, graduation standards, content standards, process standards

\section{A. Background}

\section{INTRODUCTION}

The involvement of subordinates in the decision-making process has an objective to make the decisions more profoundly because they are thought by many people. In particular, if the decision covers various aspects such technical, administrative, human relations, financial, and so on. Subordinates feel that they are involved in the decision-making process, their involvement is in the form of inputs and opinions, while the final decision remains in the leadership, who has the authority to make decisions. However, in a group decision, the decision must be made by the leadership group, not by a single leader.

Likewise, the decision-making process at the level of educational units or schools should involve teachers as part of educational organizations. "Teachers as educators must have adequate quality because they are one of the microcomponents of a 
very strategic education system and play a significant role in the school education process" (Suyanto and Hisyam in Syamsi, 2000: 43). In developing the professional duties of teachers as educators, teachers and trainers are expected to be able to make a significant contribution to the achievement of the goals that have been set. However, it is inevitable that good and bad performance of a teacher is affected by various factors from both individuals and their work environment such as capability and skills to carry out learning tasks, family background, lack of infrastructure, insufficient human resources, inadequate compensation, and unsatisfactory leadership style of headmasters, especially in the decision-making process.

Providing subordinates with encouragement to have a commitment in carrying out their duties is important for a leader in achieving goals as stated by Wibowo (Syamsi, 2000: 44) that "Subordinates will improve their performance if they have a commitment to what they are responsible for. Although it requires improvement, it will encourage people." Motivating subordinates is very important for a leader so that the work can be done successfully, as written by Kambey (1999: 135) "Every job in any field, in addition to requiring personal capabilities or skills, requires sufficient motivation in a person, so that the work can be successfully done as well as possible".

Decision-making reflects a leader's character. Therefore, whether a decision made is good or bad is not only judged after the consequences have occurred, but the decision is one of the forms of leadership, so that:

1. Decision theory is a methodology for structuring and analyzing uncertain or risky situations, in this case decision is more perspective than descriptive.

2. Decision making is a mental process in which a manager obtains and uses data by using other means, shifting answers to find relevant information and analyzing data: managers individually and in teams organize and monitor information.

Decision making is a process of choosing among alternatives - alternative actions to overcome the problem of superior quality are largely determined by the headmaster's. Besides, the behavior and ways of the principal as a leader and the pattern of decision making greatly affect the behavior and the way the principal as a leader in decision-making patterns greatly affects the behavior and attitudes of his followers. In this case, how the principal influences stakeholders to play a maximum role in achieving goals. Therefore, the focus of decision making is on the ability to analyze the situation by obtaining information as accurately as possible so that problems can be resolved (Rivai in Syamsi, 2000: 42). Based on the observations of decisionmaking researchers at SMP N 1 Kalawat, and SMP N 2 Kauditan, the decision-making process, implementation of decision making, monitoring of decision making, and follow-up monitoring of decision-making results have not been implemented properly. Therefore, the researcher chose the title "Decision Making for School Principals in Junior High Schools in North Minahasa Regency (Multi Case Study at SMP N 1 Kalawat and SMP N 2 Kauditan).

\section{B. Limitation of Problem}

Decision making is the process of choosing among alternative actions to solve a problem. The guidelines for how to make effective decisions are: Knowing the causes of problems, knowing the causes if the problem is allowed to drag on, formulating the problem clearly, making sure that the objectives of the decision do not conflict with the goals of the organization as a whole, involving subordinates in the decision-making process, having to be confident that the implementation of the decision will be successful, assessing the results of the implementation of the decision, using a flexible approach, (Syamsi, 2000: 14). From this concept of decision making, the problems are formulated as follows

1. How are the subordinates involved in the of decision-making process of the Headmasters of SMP N 1 Kalawat and SMP N 2 Kauditan? 
2. How are the decisions made by the headmasters of SMP N 1 Kalawat and the head of SMP N 2 Kauditan in relation to graduation standards?

3. How are the decisions made by the headmasters of SMP N 1 Kalawat and SMP N 2 Kauditan in relation to content standards?

4. How are the decisions made by the headmasters of SMP N 1 Kalawat and SMP N 2 Kauditan in relation to management standards?

\section{Research Objectives}

In line with the aforementioned formulation of the problems, this research aims to:

1. Describe and analyze the involvement of subordinates in the decision-making process of the headmasters of SMP N 1 Kalawat and SMP N 2 Kauditan;

2. Describe and analyze the decision-making of the headmasters in relation to graduation standards at SMP N 1 Kalawat and SMP N 2. Kauditan;

3. Describe and analyze the decision-making in relation to content standards at SMP N 1 Kalawat and SMP N 1 Kauditan;

4. Describe and analyze the decision-making in relation to management standards at SMP N 1 Kalawat and SMP N 2 Kauditan.

\section{A. Concepts of Leadership}

\section{THEORETICAL REVIEW}

Leadership can determine whether an organization is able to achieve the goals that have been set. Leadership has a series that is manifested as the ability to influence the behavior of others in certain situations so that they are willing to work together to achieve agreed goals. Tannenbaun, Wescler, and Massarik (Chairunnisa, 2016: 105) argue that leadership has an interpersonal influence that is carried out in situations through a communication process and is directed at achieving goals. According to MiftaToha (Chairunnisa, 2016: 106), leadership can also be defined as an activity of influencing other people or an art of influencing the behavior of others or an art of influencing human behavior, both individually and in groups. Leadership can take place anywhere, as long as someone shows their ability to influence the behavior of others towards the achievement of certain goals. Stongnil, Bas (Chairunnisa, 2016: 107) states that leadership is an interaction between group members. Leadership occurs when a member of a group modifies the motivation or abilities of others in the group.

Tati Rosmiyanti and Dedy Kurniady (TIM Dosen, 2009: 125) wrote definitions of leadership according to experts as follows:

1. Ralph M. Stogdill argues that leadership is a process of influencing group activities organized towards goal determination and achievement.

2. Sondang P. Siagians argues that leadership is a motor or driving force of all the resources and tools available to an organization.

3. Robert Dubin argues that leadership in an organization means the use of power and making decisions.

4. Fred E. Fiedler argues that leadership is an individual in a group who provides directive and organizing tasks that are relevant to group activities.

5. Kimball Wiles argues that leadership is any contribution to the establishment and attainment of group purpose. 
Carter V. Good gives two definitions of leadership, namely: “(1) The ability and readiness to inspire, guide, direct, or manage other. (2) The role of interpreter of interest and objectives of a group, to grow up recognizing and accepting the interpreter as spokesman”, (TIM Dosen, 2009: 125-126).

Mulyasa (Kompri, 2014: 207) states that headmaster is a person who has professional abilities who work based on a mutually agreed pattern of professional performance to facilitate and support successful learning. The success of learning is closely related to the performance of teachers who carry out their duties. In order to achieve optimal teacher performance, a democratic and professional leadership of the headmaster is required. Therefore, it can be seen that the leadership of the headmaster is highly influential on teacher performance. Accordingly, it is suspected that there is a correlation between headmaster leadership and teacher performance. This means that the better the leadership of the headmaster, the better the performance of the teachers. On the contrary, the worse the leadership of the headmaster, the lower the performance of the teachers.

According to Mulyasa (Tarhid, 2017: 141-155) states that in the new paradigm of education management, a headmaster should function as educator, manager, supervisor, leader, innovators and motivator (EMASLIM). The leadership success of the headmaster can be measured using these six dimensions. The demands on schools are increasing. This fact demands the accountability of the headmaster to improve the academic aspects of students in facing challenges in the new century. One of the challenges is continuous school improvement. Therefore, according to Sorenson et al. (Ansyar, 2015: 426), the headmaster should become an instrument of school change. This means that the headmaster should take the initiative to make changes to the curriculum to improve student learning achievement continuously. This should be an important mission of the headmaster, serving as a call to which the headmaster needs to respond positively, if he/she wants to be successful as a curriculum and learning leader in addition to being an effective school leader (Sorenson at al. in Ansyar, 2015: 426). Research reveals that effective schools, according to Reynolds and Teddlie \& Raynolds (Ansyar, 2015: 426) are synonymous with the characteristics of effective leadership.

Leadership is a contribution from someone in cooperative situations. Leadership and group are two things that cannot be separated from one another. There is no group without leadership, and leadership only exists in situations of group interaction. A person cannot be said to be a leader if he is outside the group; he must be in a group where he plays leadership roles and activities.

\section{B. Concepts of Decision Making}

Davis (Syamsi, 2000: 3) states that "Decision is a result of solving problems faced with tasks". Furthermore, Terry (Syamasi, 2000: 3) argues that "Decision-making as a key part of managerial activities is a process through which a series of activities are selected, which reflects the best alternative action for problem solving”. Reksogadiprodjo and Handoko (1982: 144) compile definitions of decision-making from experts as follows:

1. Curits R. Finch and Robert L. Mcgough (Reksogadiprodjo and Handoko, 1982: 144) in their book entitled "Administering and Supervising Occupational Education" defines decision-making as an action and a number of existing alternatives. They also view decision-making as a basic function of leadership.

2. Meanwhile, H. Malayu S.P. Hasibuan (Nur A, 2015: 131) gives a definition that decision-making is a process of determining the best decision and a number of alternatives for carrying out activities in the future.

3. Furthermore, according to Max (Chairunnisa, 2016: 138) "Decision making is commonly defined as choosing from among alternatives".

4. According to G.R. Terry, Iqbal Hasan (Chairunnisa, 2016: 140), "Decision-making can be defined as the selection based on same criteria of one behavior alternative from two or more passible alternatives".

5. Meanwhile, Sondang P. Siagian (Chairunnisa, 2016: 140) states "Decision-making is a systematic approach to the essence of a problem of collecting facts and data, determining which alternatives and taking the most appropriate action.

6. According to Prajudi Atmosudirjo, decision is a closing of the thought process about a problem to address questions of what should be done to solve the problem by making a choice of one alternative (Chairunnisa, 2016: 140) 
Decision among alternatives contains three definitions, namely: 1) There is a choice based on logic or consideration; 2) One of the best out of several alternatives must be chosen; 3) There are goals to be achieved and those goals are getting closer to those goals (James A.f.Stoner in Chairunnisa, 2016: 140). Therefore, it can be concluded that decision is the result of resolving the problems faced firmly. A decision must be able to address questions about what is discussed in relation to planning.

Based on this definition, it can be seen that decision-making is not a trivial or easy activity. Decision is born from a long and complicated process in which there is intensive discussion. Decision-making is the ability to analyze situations by obtaining as accurate information as possible in order to solve problems. It is very clear that, in schools, decision-making is a shared responsibility for which the process must involve all related parties such as teachers, administrators, parents, committees, the community if necessary. There is a decision-making that only involves a group of people, for example, only the leaders, but the process must involve the leaders and not only determined by the headmaster.

\section{A. Type of Research}

\section{RESEARCH METHODOLOGY}

A qualitative research is a method of exploring and understanding meanings that a number of individuals or groups of people think comes from social or human problems. Its process involves important efforts such as asking questions and procedures, collecting specific data from participants, analyzing data inductively (Creswell, 2017: 121). This research attempted to reveal the model of decision-making for multi-cases by headmasters in SMP Negeri 1 Kalawat and SMP Negeri 2 Kauditan.

\section{B. Data and Data Source}

Data collected in this research were classified into two types of data, namely primary data and secondary data (Yunus in Nurza, 2017: 37). Primary data were data obtained directly in the field by means of direct interviews with informants. Secondary data included minutes of meeting, letters and school documents.

\section{Method of Data Collection}

1. In-depth interviews in relation to the decision-making of headmasters. The interview activity in this research refers a conversation between the researcher and the informants which was conducted face-to-face. It was related to the decisionmaking for multi-cases by the headmaster of SMP N 1 Kalawat, and the decision-making for multi-cases by the headmaster of SMP N 2 Kauditan. The interview activity in this research aimed to provide information about the headmaster's decision making and the teacher's feedback to the headmaster's decision making and student's feedback to the headmaster's decision making and its implementation in Minahasa Regency.

2. Field observations. Field observation, according to Bogdan and Biklen (1998), is "a pure observation, an observation that made deliberately so that the object being observed does not change due to the presence of the researcher". The observations were made directly on the object of research to strengthen and round out the truth from the results of interviews with informants

3. Documentation study. The documentation study in this research was intended to study a number of documents related to the research focus, namely the model of decision-making by the headmasters of SMP Negeri 1 Kalawat of Kalawat Subdistrict and SMP Negeri 2 Kauditan of Kauditan Subdistrict.

\section{Method of Data Analysis}

Data analysis in a qualitative research was carried out simultaneously with the data collection process. The final analysis was conducted after the field observation, or the analysis was carried out after the data from the field had been collected. Therefore, research findings in the field were formed into theory, not from existing theories but developed from data in the field. This publication is licensed under Creative Commons Attribution CC BY. 
This type of research was multi-case, so that data analysis was carried out in two stages: single data analysis (individual case analysis) and cross case data analysis.

\section{A. Research Results}

\section{RESEARCH RESULTS AND DISCUSSION}

The results of the interview regarding the model of decision-making by the headmaster of SMP N 1 Kalawat of North Minahasa were as follows:

1. Decision Making Process: Giving subordinates opportunities in the decision-making process, namely giving input or questions, recording input, deliberating, concluding, deciding, directing, conducting approaches, distributing tasks, providing incentives, being patient, distributing tasks until they were done.

2. Graduation Standards: The headmaster carried out his duties very well, namely facilitating, supervising teacher preparation (learning tools), teaching and learning activities, carrying out assessments, coordinating with related parties, expressing good character (being a model for healthy schools).

3. Content Standards: Establishing a school curriculum making team, making curriculum, conducting supervision and evaluation.

4. Process Standards: Facilitating, coordinating, and supervising the making of lesson plans and learning activities in accordance with the 2013 curriculum, and conducting evaluations

The results of the interview regarding the decision-making by the headmaster of SMP N 2 Kauditan of North Minahasa were as follows:

1. Decision-Making: The Headmaster of SMP N 2 Kauditan were providing opportunities for subordinates to give input, deliberating, distributing tasks, paying attention to needs, finding solutions to solve problems.

2. Graduation Standards; Organizing, motivating, coordinating, carrying out curricular and extra-curricular activities, conducting supervision, motivating students, holding quizzes, holding school examination and computer-based National examination, creating and implementing school rules.

3. Standard contents: Establishing a curriculum development team, making a curriculum, distributing tasks in teams, checking teacher administration, conducting classroom supervision, checking journals once a week.

4. Process Standards: Implementing the school curriculum, checking teacher administration, carrying out clinical supervision and providing reinforcement.

\section{B. Discussion}

Based on the results of the research, there were several aspects to be discussed in relation to the decision-making of headmasters at SMP N 1 Kalawat and SMP N 2 Kauditan, as explained below:

1. National Education Standards

Serving as the key driving force for school development and advancement and being responsible for improving the quality of school, the headmaster must be sensitive to changes in education in order to complement and develop so that quality is maintained.

Edwar Salis (Nur 2015: 160) argues that indicators of improving the quality of education in schools are seen from the education components, including quality of graduates, quality of teachers, headmaster, school staff (administrative personnel), laboratory assistants and technicians, library staff, learning process, facilities and infrastructure, school management, curriculum This publication is licensed under Creative Commons Attribution CC BY. 
implementation, assessment systems and so forth. Equitable improvement in the quality of primary and secondary education refers to standards in accordance with applicable regulations. The main reference for the quality assurance system for primary and secondary education is by the National Education Standards (SNP), which was stipulated by the central government through the National Education Standards Agency (BNSP). SNP is the minimum standard set by the government in the education sector which must be met by the educational unit and all stakeholders in managing and administering education.

\section{Decision-Making Process at SMP N 1 and SMPN 2}

According to W. Haynes (Simon, 1991: 4), decision making is an obligation of every individual. A decision is good serving as a consideration to reach a conclusion, which is a part for all headmasters. Simple decision making may be able to emphasize a relationship between options or a selection for a case towards action from either the availability of alternatives or options to obtain the desired result. The headmaster makes decisions through a process like when planning a budget, planning an organization's work, interviewing a prospect teacher, watching student lining up for a flag ceremony or making an adjustment to a project.

The decision-making process is real in organizations, as stated by Lester Coch and John R.P. French in their study (Simon, 1991: 340) regarding participation in decision-making that "The results are clear and definite that employee participation in decision-making increases production. In educational organizations, followers of the generalization summarize a great deal of research and literature on teacher participation in decision making. 1. Participation in decision-making is positively related to teachers' satisfaction with teaching skills. 2. Teachers prefer headmaster to involve them in decision-making. 3. Decisions fail because of poor quality or because they do not accept them. 4. Teachers do not expect to be involved; in fact, too little. 5. The roles and functions of teachers and administration in decision-making are required in various problems encountered. Grey's (Simon, 1991: 9) assumes a rational model of decision-making is the most effective result if it follows four steps in the process of an investigative situation; 1) Developing alternatives; 2) evaluating alternatives; 3) Selecting one and the best; 4) Implementing.

Likewise, educational organizations encounter various types of problems so that they must be able to choose the appropriate model in order to have a positive influence on the school organization and themselves. The decision-making process of the headmaster of SMP N 1 Kalawat involved teachers, administrators and related parties. The involvement of subordinates, i.e. teachers, administrators, parents, committees and other related parties was evident in daily activities in teacher and employee meetings as well as teacher and parent meetings. The headmaster always gave subordinates opportunities to be involved in making decision, giving input, deliberating, deciding and even conditioning in order to create communication and cooperation for smoothly completing tasks. The headmaster in carrying out his duties always coordinated and collaborated with the school committee, treated his subordinates like family, recognized the strengths and limitations of each member, filled in the gaps in work, gave incentives and distributed tasks until they were done. The involvement of subordinates in the decision-making process of the Headmaster of SMP N 2 Kauditan went well by involving subordinates giving input, deliberating, making a clear distribution of work, supervising, paying according to workload, finding solutions to solve problems.

\section{Decision-Making of Headmasters in Relation to Graduation Standards}

Graduate Competency Standard refers to a qualification of the ability of graduates which includes attitudes, knowledge and skills of students that must be met or achieved from an educational unit at the primary and secondary education levels (Law number 20 of 2003). The graduate competency standards in the 2013 curriculum consist of qualification criteria for students' competency that are expected to be achieved after completing their study period in educational units at the primary and secondary education levels. Monitoring and evaluation are carried out periodically and continuously in each period in order to reveal the achievement and conformity between the graduate competency standards and graduates from each education unit and the 
ISSN 2250-3153

curriculum used in certain educational units. The results obtained from monitoring and evaluation are used as input for improving the graduate competency standards of in the future. Junior high school and Islamic Junior High School graduates must have competence in the dimensions of attitude, knowledge and skills.

Likewise, the decision-making of the headmaster of SMP N 1 Kalawat were related to preparing students by developing their potential, equipping them with knowledge in accordance with the 2013 curriculum, conducting assessments for every subject starting from daily scores, mid-semester scores, semester scores including knowledge, attitude, and skills for grades 7 and 8. Meanwhile, for grade 9, graduation requirements were completion of study for six semesters, added with school exam scores and computer-based national examination scores. In addition to curricular activities, there were also extra-curricular activities, such arts, sports, scouting and Junior Red Cross. This school was a pilot school for a healthy school (it has counseling services, healthy toilet, beautiful garden, 3 types of trash bins, drinking water provided in the classroom). The learning implementation went well. Before learning began, the teacher in charge and security guard were already present at the school ready to welcome the students by shaking hands. At the school, students were trained to pay attention to personal hygiene and the environment. The headmaster monitored the implementation of activities, created an effective teaching and learning environment, distributed tasks as needed, motivated, improved teacher competence, improved administration, improved the welfare of teachers and employees by working together to build entrepreneurship with the aim of improving the welfare of its members. Excellent character development involved all school members. The implementation of learning in SMP N 2 had slight differences, namely implementing the 2013 curriculum in learning, exercising supervision, motivating, teachers providing enrichment for learning materials, giving more exercises, making analyzes, conducting assessments.

Tyler (Chairunnisa, 2016: 301) describes education as a process in which there are three things that we need to distinguish, namely educational goals, learning experience, and learning evaluation. Evaluation is intended as an activity to see the extent to which educational goals reflect the desired behavior changes in students, so what is important in the evaluation process is to check the extent to which the desired behavior changes have occurred (Tyler in Chairunnisa, 2016: 302). By obtaining information about the extent to which these educational goals have been achieved by students individually or in groups, decisions can be made about what actions need to be taken regarding the teaching program and the student concerned. The follow-up of evaluation results that directly concern the interests of students is in the form of providing guidance in order to improve the results that have been achieved and to plan study programs for each student.

According to M. Yudah (Inriyani, 2017: 1), extracurricular activity as a program outside school hours are developed to facilitate the curricular program with this activity. This activity is carried out by planning student activities, namely activities that must be carried out at school in order to achieve educational goals and to attempt to shape character, personality development of talents, interests and uniqueness of students.

\section{Decision-Making of Headmasters in relation to Content Standards}

Curriculum implementation seeks to transfer curriculum planning into operational action. Curriculum evaluation is the final stage of curriculum development to determine the extent of learning outcomes, the level of achievement of the programs that have been planned, and the results of the curriculum itself. The curriculum development does not only involve people who are directly related to education, but involves many people, such as politicians, businessmen, parents of students, and other elements of society interested in education (Kompri, 2014: 172-173)., as seen in Figure 1.

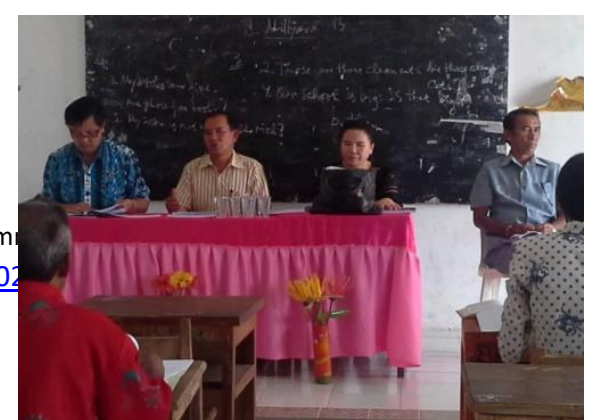




\section{Figure 1. School Curriculum Development Meeting}

The main challenge today is designing a relevant and accountable curriculum. Accountability can be achieved partially by matching curriculum. Matching means that standards, content, assessment, and teaching strategies are coherent, and create a complementary match (Drake in Kompri, 2014: 174). According to Marzano, quoted by Stronge (Kompri, 2014: 174), one of the factors that must be considered at the school level is a guaranteed and possible curriculum to be implemented.

Law number 20 of 2003 concerning National Education System article 36 paragraph (3) states that curriculum is developed in accordance with the level and type of education within the framework of the Unitary State of the Republic of Indonesia by considering: 1) Increase in faith and piety; 2) Increase in noble character; 3) Increase in potential, intelligence, and interest of students; 4) Regional and environmental potential diversity; 5) Regional and national development demands; 6) Demands of the world of work; 7) Development of science, technology and art; 8) Religion; 9) Dynamics of global development; and 10) National unity and national values;

Serving as one of the components of education, the curriculum plays a very important role in delivering the expected educational goals. Therefore, it is the main force that affects and shapes the learning process. Mistakes in the curriculum development will cause the failure of an education. Herman H. Hornee as quoted by Iskandar Wiryokusumo and Usman Mulyadi (Kompri, 2014: 175) provides three bases for curriculum development: 1) Psychological basis: used to meet and identify competence obtained and needs of students; 2) Sociological basis: used to identify the demands of society for education; 3) Philosophical basis: used to identify the values to be achieved.

Based on programs and plans that have been made, students carry out learning activities to develop and change behavior in accordance with predetermined goals (Kompri, 2014: 175-176). This was evident in the curriculum developed by the school based on the 2013 curriculum. It was developed together by headmaster, committee, teachers, and even stakeholders. However, the headmaster had to be responsible from the development to its application in learning. For example, in developing the curriculum for SMP N 1 Kalawat, the headmaster established a curriculum development team consisting of teachers, administrators, school committees, and supervisors to develop the school curriculum based on the 2013 curriculum, including: basic framework, curriculum structure, learning load and calendar, supervision and evaluation, making syllabi and learning implementation plan (RPP), annual program (PROTA) and semester program (PROSEM), having documents for teachers and parents meeting, setting the Minimum Mastery Criteria for school and the Minimum Mastery Criteria for subjects. Likewise, SMP N 2 Kauditan had a school curriculum developed by a curriculum development team, consisting of teachers, headmaster, and committees. The school curriculum was based on the 2013 curriculum.

The curriculum in a school is a tool or effort to achieve the educational goals desired by the school, which are considered appropriate and crucial in achieving educational goals, so that one of the steps to be done is to review the goals that have been used by the school. (Soetopo \& Soemanto in Junaedi, 2012: 1). This means that if the desired goals have not been achieved, the tools used must be reviewed to achieve such goals, in this case the curriculum. The existence of the curriculum as a structured learning organization is a preparation for students. Students are expected to obtain a number of new experiences which in the future can be developed in line with their development. 
Moreover, the curriculum for teachers or educators serves as : 1) A guideline for working in making and organizing learning experiences for students; 2) A guideline for evaluating the development of students in absorbing a number of experiences provided.

\section{Decision-Making of Headmasters in Relation to Process Standards}

Regulation of the Minister of Education and Culture number 22 of 2016 concerning process standards for primary and secondary education confirms that process standards refer to criteria for the implementation of learning in educational units to achieve graduate competency standards. The process standards are developed by referring to the graduate competency standards of and content standards that have been set in accordance with the provisions in Government Regulation no 19 of 2005 concerning national education standards as amended by Government Regulation number 32 of 2013 concerning regulation on government regulation number 19 of 2005 concerning national education standards. The learning process in educational units is held in an interactive and inspiring manner. It also provides sufficient space for initiative, creativity, and independence according to the talents, interests and physical and psychological development of students, learning, and assessment of the learning process in order to increase the efficiency and effectiveness of the achievement of graduate competencies as shown in Figure 2 below:
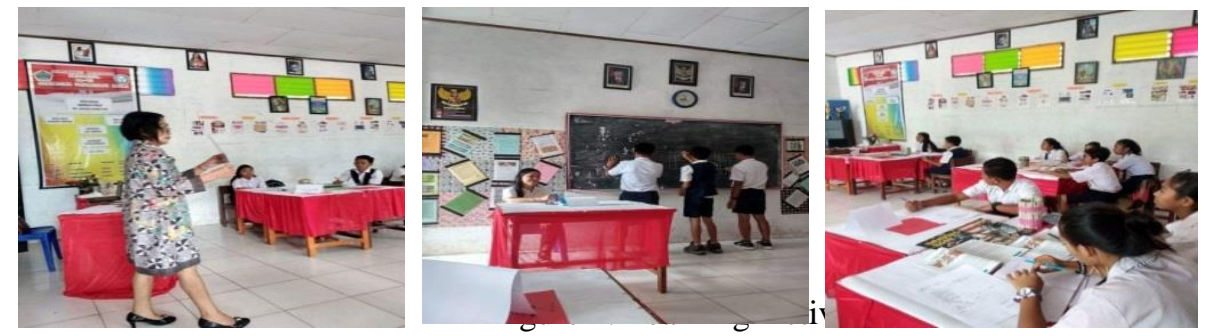

In accordance with graduate competency standards, learning standards include the development of the dimensions of attitude, knowledge and skills, which are elaborated for each educational unit. The three dimensions of competence have different acquisition trajectories(psychological processes). Attitude is acquired through the activity of "memorizing, understanding, applying, analyzing, evaluating, creating”, skills are acquired through the activity of “observing, questioning, trying, reasoning, presenting and creating”. The characteristics of competency along with differences in acquisition trajectories also influence the characteristics of process standards. In order to strengthen the scientific approach, integrated theme (themes between subjects) and themes in one subject, it is necessary to apply discovery/inquiry learning. In order to encourage the ability of students to produce contextual work, both individually and in groups, it is highly recommended to use a learning approach that produces problem solving-based work (project-based learning). The learning process is entirely directed at the development of the three dimensions which are not separable from each other. Therefore, the whole learning process creates personal qualities in attitude, knowledge and skills.

In student management, teachers play a more indirect role. Some of the roles of teachers in student management are serving as a committee in admitting new students, during orientation period the teacher makes students able adapt quickly to their new school environment, teachers playing a role in recording student attendance, teachers motivating students to always achieve high, teacher should be an exemplar in creating school discipline so that students can imitate it. The learning process at SMP N 1 can be described as follows: before the learning activities, the headmaster together with the teachers held a workshop, distributed assignments, gave decrees, checked teacher administration and monitored the implementation of learning, enhanced learning in an interactive, inspirational, and fun way; improving teacher competence, built communication and coordinated with committees, parents, teachers, administrators, alumni and other institutions such as the police, public health centers, drug agencies, government and local communities; Had rooms and student work, had achievements, improved the welfare of teachers and employees. Overall, the management of SMP N 2 Kauditan was already good by implementing curriculum, supervising 
administration and implementing learning, having achievements; carry out learning in an interactive, inspiring, and fun way; improving the implementation of education, improving education, affection to balance the development of cognition, and fostering the next generation to be able to continue development. The education manager should be responsive to changes in order to respond. One of the ways is by changing or adjusting the organizational structure, establishing a new structure that is suitable and taking a step forward, namely creative.

\section{Program Planning}

The role of the headmaster as a driving force in all activities at school requires that the headmaster has more abilities than other members of the school. The success of an educational institution reflects the competence of the headmaster in managing all kinds of action for the benefit of the school. The managerial Competence includes: 1) Able to formulate school planning; 2) Able to develop school organization; 3) Able to lead teachers and staff; 4) Able to manage school facilities and infrastructure; 5) Able to manage school community relationships in order to seek support for ideas, learning resources, and school funding; 6) Able to manage students, especially in the context of admitting new students, and developing student capacity; 7) Able to manage curriculum development and teaching and learning activities in accordance with the direction and goals of national education; 8) Able to manage school finances in accordance with the principles of accountable, transparent and efficient management; 9) Able to manage school administration in supporting school activities; 10) Able to managing school special service units in supporting learning activities and student activities at school, 11) Able to apply entrepreneurial principles in creating innovations that are useful for school development; 12) Able to create a work culture and climate that is conducive to student learning; 13) Able to manage school information in supporting program development and decision-making; 14) Skilled in utilizing advances in information technology; 15) Skilled in managing production/service activities in supporting school funding sources and as a source of student learning; 16) Able to carry out supervision of the implementation of school activities in accordance with prevailing supervisory standards.

\section{A. Conclusion}

\section{CONCLUSION}

1. SMP N 1 Kalawat; a) The Decision-Making Process of the Headmaster of SMP N 1 Kalawat; Cooperating with committees, teachers, parents and other institutions, providing opportunities for subordinates to give input in the decisionmaking process, recording important matters, deliberating, concluding and deciding. Moreover, in more complex matters, before conveying to parents, the headmaster first coordinated with the committee, and in conveying to parents the headmaster asked for support from the School Committee: Directing, approaching, distributing tasks to until they were done, handling patiently, providing incentives. b) the Decision Making of the Headmaster of SMP N 1 Kalawat in relation to the graduation standards; Distributing team assignments for each activity, making and implementing school rules, motivating teachers, inviting parents to cooperate in guiding students, carrying out curricular and extracurricular activities, providing assistance and supervision, implementing curriculum in learning, maximizing student learning activities, providing examples, motivating students, holding daily quizzes, semester tests, school examination, National-based School Examination (USBN), Computer based National Examination (UNBK). c) The Decision-Making of the Headmaster of SMP N 1 Kalawat in relation to Content Standards: Establishing a school curriculum development team, making school work plans, making a school curriculum, conducting supervision and evaluation; d) The Decision-Making of the Headmaster of SMP N 1 Kalawat in relation to the Standard Process: Coordinating, facilitating, supervising the development of learning plans and learning activities according to the 2013 curriculum, holding interactive, inspirational and fun learning, improving teacher competence, improving teacher welfare, cooperating with related institutions.

2. SMP N 2 Kauditan; a) The process of decision-making of the Headmaster of SMP N 2 Kauditan: Involving subordinates by providing input, deliberating, distributing work, finding solutions for solving problems, conducting supervision, This publication is licensed under Creative Commons Attribution CC BY. 
providing incentives. b) The Decision-Making of the Headmaster of SMP N 2 Kauditan in relation to the Graduation Standard: Coordinating, motivating, carrying out curricular and extra-curricular activities, supervising, motivating students and teachers, holding quizzes, school exams and computer-based national examination; Making and implementing school rules, paying according to workload. c) The Decision-Making of the Headmaster in relation to the content standards: Establishing a curriculum development team, making a school curriculum according to the 2013 curriculum, distributing assignments, checking teacher administration, conducting supervision, checking teacher journals once a week. d) The Decision-Making of the Headmaster in Relation to Process Standards: Implementing the school curriculum, organizing an interactive, inspirational and fun learning, checking teacher administration, carrying out clinical supervision, and providing reinforcement, paying according to workload.

\section{B. Suggestions}

1. The headmasters build good cooperation with related parties and seeks to adapt to new things that can improve the quality of the school.

2. The headmasters strive to complement the shortage of existing teachers and education personnel, to involve teachers and other education personnel in training, socialization, Deliberation of Subject Teacher (MGMP), workshops; monitoring, directing and motivating.

3. The headmasters develop and implement the school curriculum.

4. The headmasters formulate the vision, mission and goals of the school.

5. The headmasters provide facilities and infrastructure in accordance with the school's needs.

6. The headmasters manage school funds effectively and efficiently.

7. The headmasters build entrepreneurship among school members, for example a cooperative.

8. The headmasters conduct a self-evaluation at least once a year and is willing to be accredited in order to maintain and improve the quality of the school.

\section{BIBLIOGRAPHY}

Ansyar M, 2015 Kurikulum. Hakekat, Fondasi, Desain, Dan Pengembangan. Jakarta. Kencana Prenadamedia Grup.

Bongdan R. C, \& Biklen S. K, 1998. Qualitative Research for Education An Introduction to Theory and Methods. Needham Heights, MA. Ellyn Bacon, Inc.

Chairunnisa C, 2016. Manajemen Pendidikan Dalam Multi Perspektif. Jakarta. Raja Grafindo Persada.

Creswell W. John, 2010. Research Design Pendekatan Kwantitatif, Kualitatif Dan Mixed. Jogyakarta. Penerbit, Pustaka Belajar. Creswell W. John, 2017. Research Design Pendekatan Kwantitatif, Kualitatif Dan Mixed. Jogyakarta. Penerbit, Pustaka Belajar. Inriyani Y, Wahjoedi, Sudarmiatin. 2017. Peran Kegiatan Ekstrakurikuler Untuk Meningkatkan Prestasi Belajar IPS. Universitas Negeri Malang.

Junaedi J, 2012. Jenis-Jenis Dan Fungsi Kurikulum. Jurnal.

Kambey, Daniel C. 1999. Manajemen Sumber Daya Manusia. Manado. Yayasan Tri Ganesa Nusantara.

Kompri, 2014. Manajemen Pendidikan 2. Alfabeta cv. Bandung.

Nur A, 2015. Dasar - Dasar Manajemen Pendidikan. Jakarta. Gosyen Publishing Raja Grafindo Persada.

Nurza A, 2017. Konsep Pendidikan Islam Perspektif Mahmud Yunus Dan Implikasinya Terhadap Pembelajaran PAI di Sekolah.

Rawis J. 2000 Partisipasi Guru Dalam Pengambilan Keputusan di Sekolah Berprestasi SMU Negeri 1 Manado.

Reksogadiprodjo, Sukanto dan Hani Handoko. 2001. Organisasi PerusahanTeori Struktur dan Perilaku. Yogyakarta. BPFE.

Simon H. A, 1991. Decision Making In Schools. Administrative Behavior.

Syamsi I, 2000. Pengambilan Keputusan Dan Sistem Informasi. Jakarta. PT Bumi Aksara.

Tarhid F, 2017. Kepemimpinan Kepala Sekolah dalam Meningkatkan Profesionalisme Guru. Jurnal Kependidikan. IAIN Purwakerto.

TIM Dosen Administrasi Pendidikan Universitas Pendidikan Indonesia. 2009. Manajemen Pendidikan. Bandung. ALFABETA. 